\title{
EFFECT OF DARUHARIDRA RASAKRIYA ON PRAVAHIKA (AMOEBIASIS)
}

\author{
S. Pavan Kumar ${ }^{*}$, M. Vidyasagar ${ }^{2}$, P. Vasanth ${ }^{3}$
}

\begin{abstract}
$\underline{\text { Abstract }}$
Pravahika is a disease described in the Ayurvedic texts which can be compared with the Amoebiasis. It is cause by the Infection of the Protozoan Entamoeba histolytica. It may be diagnosed by the symptoms of diarrhea, precipitate stools, abdominal cramps flatulence etc. Laboratory investigations included the stool examination for the presence of amoebic cysts. For the treatment of the disease drugs which can act as deepana, paachana, grahi, sthambhana etc are to be selected. So Daruharidra having the above properties was selected for the study. It was given in the form of Raskriya. The method adopted for the study is open clinical method of study. For the present study 30 patients showing positive stool examination for the presence of amoebic cysts were taken for the study and Daruharidra Rasakriya was administered in a dosage of $300 \mathrm{mg}$ for 10 days. The net result of the study showed good response in $80 \%$ of the patients. Statistical analysis of the mean difference before and after treatment of the parameters showed highly significant result $(\mathrm{p}<0.0001)$.
\end{abstract}

Key words: Daruharidra, Rasakriya, Pravahika, Amoebiasis, Ayurveda

\section{Introduction:}

Pravahika is a disease described in the Ayurvedic texts which can be compared with the diarrhoeas and dysenteries of the present day medical literature. It was described in the shleshmika atisaara.(1) (Sushruta Samhita, Uttara Sthana 40/ 138-160). It is described with various synonyms like Purisha kshaya, Nischaraka or Nissaaraka, Bhimbhisi etc. it occurs because of the Excessive consumption of the heavily digested, oily or dry, very hot, liquid and sticky foods, incompatible foods, excessive eating and irregular food habits are the causative factors of the disease. It also occurs as a complication of the panchakarma. Psychological causes like fear, etc. consumption of the contaminated water and excessive consumption of the alcoholic beverages and allergic foods also play a major role. Suppression of the vega (natural urges) and infections (krimi) are also the commenest causes of Pravahika.

It expressed by the symptoms of pain in the chest, abdomen and anal canal, gatraavasaada (tiredness), anilasannirodha (flatulence), vitsangha (constipation), adhmaana (bloating) and avipaaka (indigestion). The main feature of the disease is the painful and forceful elimination less or more quantity of the sticky (picchila) stool. The other features of Pravahika are abdominal and anorectal pain due to vaata, burning pain due to pitta, kapha mixed sticky stools due to kapha and blood mixed stool due to raktha involvement (1).

The disease is compared with amoebic and other forms of dysenteries of the modern medical literature.

Amoebiasis is the next major cause of death, next to Malaria, in the developing countries. It occurs because of the poor sanitation. It is cause by the Infection of

1*. Corresponding Author: National institute of Indian Medical Heritage, Hyderabad. Tel +919394749355,

E.mail pavansangu@gmail.com

2. Professor and HOD, Department of Drayaguna, Ayurvedic Medical college, Koppa.

3. Retd.HOD, Dr. BRKR Govt Ayurvedic College, Hyderabad 
the Protozoan Entamoeba histolytica. The parasite was first described by Losch (1875) in Russia.

The life cycle of E. histolytica consists of two stages: an infective cyst and an invasive trophozoite. The trophozoites measure $10-50 \mathrm{~mm}$ in diameter and contain a single nucleus with a central karyosome. The cysts measure $10-15 \mathrm{~mm}$ in diameter and typically contain four nuclei.

E. histolytica cysts are resistant to acidification, chlorination and desiccation. They are capable of surviving in a moist environment for several weeks and are spread via the ingestion of faecally contaminated food or water. After ingestion of the cysts by a human host, excystation occurs within the lumen of the small intestine. During excystation, nuclear division is followed by cytoplasmic division, giving rise to eight trophozoites. The trophozoites then reside in the lumen of the caecum and large intestine, where they adhere to the colonic mucus and epithelial layers; re-encystation of the trophozoites occurs within the lumen of the colon, resulting in the excretion of cysts in the faeces and continuation of the life cycle.

E. histolytica can spread in the bloodstream (haematogenously) after it has penetrated the colonic epithelium and can establish persistent extraintestinal infections (most commonly amoebic liver abscess).

The clinical forms of intestinal Amoebiasis may be

1. Asymptomatic cyst carriers - It consists of colicky lower abdominal pain and increased frequency of bowel movements with loose watery diarrhea.

2. Symptomatic. The symptomatic intestinal Amoebiasis can progress from mild diarrhoea (non-dysenteric colitis with intermittent diarrhea, mucus, abdominal pain, flatulence and weight loss) to severe haemorrhagic dysentery (acute amoebic dysentery with presence of blood and mucus in the stool, accompanied by abdominal pain, tenderness, tender Hepatomegaley and rectal tenesmus) with or without complications.

Laboratory diagnosis can be done by:

- Direct examination of colonic exudates obtained at sigmoidoscopy or of freshly passed stool as a saline wet mount.

- Sigmoidoscopy and

- Barium enema examination

- The Amoebic Flourescent Anti-Body Titre (FAT)

\section{Treatment:}

The treatment for this condition is aimed at administering the drugs which have the properties of langhana, deepana, paachana and graahi. After the infection reduces sthambhana dravyas can be administered.

Rationale in the selection of the drug:

Many internal medications are mentioned in Ayurvedic texts for the treatment of Pravahika. Daruharidra Rasakriya is selected for the present study as it has the properties of deepana, paacana, grahi etc which are more suitable for the control of Pravahika.

Daruharidra (Berberis aristata, Berberidaceae) is one of the important medicinal plants used by the Ayurvedic physicians since ages for various ailments. It is also known by the synonyms Peetadru (stems are yellow in colour), Kaleyaka (It removes doshas out of the body), Daarvi (It washes out doshas), Pacham pachca (Increases digestive power), Parjani (It prevents the diseases), Katamkateri (It removes the doshas, which cause obstruction to the srotos) etc. (2)

It is said to be used in diseases like Prameha, Kusta, Rajayakshma, Unmaada, Apasmaara, Kshatha, Kshaya, Swayathu, Arshas, Grahani, Paandu, Visarpa, Visha, Vrana, Vaataraktha, Mukha roga, Hikka, Shwaas, Yonivyapath, Netra roga and Atisaara. (2,3) 
The chief chemical content in it is Berberine $\left(\mathrm{C}_{20} \mathrm{H}_{17} \mathrm{NO}_{4}\right)$. Berberine has been proved to have wide range of pharmacological activites like antimicrobial activity against a variety of intestinal parasites like Entamoeba histolytica, bacteria, fungi, protozoans, helminths, chlamydia, and viruses. It is also useful in ocular trachomal infections, cardio-vascular diseases like tachyarrythmias etc. (4)

\section{Mode of preparation of Rasakriya(3):}

Rasakriya is the form of preparation of the acqueous extract of the plant materials used by the Ayurvedic physicians. In this the 1 part of the $\operatorname{drug}(\mathrm{s})$ are made into coarse powder and boiled with 16 parts of water till only 4 parts of the water remains. Then it is filtered and the filtrate is again heated on a low flame till it becomes semi-solid. This semisolid mixture is again dried in shade or drier to get a solid mass of extract. This is called as Rasakriya. This is a dosage form mentioned in Ayurvedic classics which is palatable and less in dosage (approximately $1 / 10^{\text {th }}$ of the powder). This can be given in a dose of $300 \mathrm{mg}$ TID.

By considering the above mentioned the present clinical study is conducted to know the efficacy of the Rasakriya of Daruharidra (Berberis aristata, Berberidaceae) in the cases of Pravahika (Amoebiasis).

\section{Aims and objectives:}

The aim of the study is to study the effect of the Daruharidra (Berberis aristata, Berberidaceae) Rasakriya in the cases of Amoebiasis.

\section{Materials and methods:}

\section{Selection of the patient:}

30 patients who are diagnosed to have the symptoms of acute amoebic infection and positive microscopic stool examination for Entamoeba histolytica were taken for the study from Government Ayurvedic Hospital, Hyderabad.
Patients with other forms of diarrhoeas are not considered for this study.

Method of study: Open clinical study.

\section{Inclusion criteria:}

1. Patients with positive microscopic stool examination for Entamoeba histolytica cysts and having the symptoms of Amoebiasis.

2. Patients without the symptoms of severe dehydration.

3. Patients with age group between 20 and 60 years were selected for the study.

\section{Exclusion criteria:}

1. Severe dehydration

2. Patients below 20 years of age.

3. Pregnant and lactating women.

4. Elderly patients.

5. Patients having arrhythmias.

6. Patients having complications of the disease.

\section{Assessment:}

1. Based on the relief in the symptoms.

2. Stool examination for the presence of cysts.

Symptoms and grading of the symptoms:

\section{Diarrhoea:}

- 1-2 motions a day -0

- 3-4 motions a day -1

- 4 -5 motions a day -2

- Above 5 motions a day - 3

\section{Precipitate stool}

- Absent-0

- Present at certain times a day -1

- Present all through the day -2

\section{Melena}

- Absent - 0

- Few blood stains in stool -1

- Bloody stools - 2

Abdominal cramps

- Absent - 0

- Mild not affecting daily activity - 1

- Affecting daily activity - 2

\section{Flatulence}

- Absent -0 
- Mild without bloating and constipation -1

- With bloating and constipation -2

Epigastric distress

- Absent -0

- Mild burning sensation - 1

- Burning with sour belchings -2

- Burning with vomitings -3

Fatigue

- No Fatigue - 0.

- Fatigue not affecting his daily activities - 1

- Fatigue affecting his daily activities - 2

- Activities reduced due to weakness $-3$

Stool examination:

- No cysts -0

- Positive for the cysts -1

\section{Total efficacy of therapy:}

Basing on the individual score of each finding before and after treatments, the response of the treatment can be assessed. Overall effect of the treatment in each individual patient can be assessed by the below mentioned formula

Over all percentage of relief $=($ Total score of all findings before treatment -Total score of all findings after the treatment)/

Total score of all findings before treatment X 100

Classification of results:

- No response: if the efficacy is below $50 \%$.

- Poor response: If the efficacy is between 51 to $60 \%$.

- Fair response: If the efficacy is between $61-75 \%$

- Good response: if the efficacy is between $76-100 \%$.

Drugs:

Daruharidra bark was procured from Jaipur market and was tested for its microscopic identity in the Department of Dravyaguna, Government Ayurvedic College, Hyderabad. The bark is then made into course powder and Rasakriya is prepared as per the procedure mentioned for the Rasakriya by the Ayurvedic texts.
The Rasakriya thus obtained is made into $300 \mathrm{mg}$ pills (Figure 1-3).

Dose: $300 \mathrm{mg}$ TID before meals with warm water.

Route of Administration: Oral route.

Duration of the Treatment: 10 Days.

\section{Clinical assessment}

The study is based on the randomized clinical trial conducted at Govt Ayurvedic hospital, Hyderabad during the period 2002 to 2003.

Both the subjective and objective parameters are recorded before and after the treatment and analyzed statistically.

\section{Observation and results:}

Totally 30 patients were taken for the study. The patients are classified according to the age, sex, diet and place of residence. The tables showing the distribution of the patients in the above groups are as follows:

TABLE 1: SHOWING AGE WISE DISTRIBUTION OF THE PATIENTS

\begin{tabular}{|c|c|c|}
\hline $\begin{array}{c}\text { Age } \\
\text { (in } \\
\text { years) }\end{array}$ & $\begin{array}{c}\text { Number } \\
\text { of } \\
\text { patients }\end{array}$ & $\begin{array}{c}\text { Percentage } \\
\text { of patients }\end{array}$ \\
\hline $\mathbf{2 1 - 3 0}$ & 11 & 36.67 \\
\hline $\mathbf{3 1 - 4 0}$ & 8 & 26.67 \\
\hline $\mathbf{4 1 - 5 0}$ & 6 & 20 \\
\hline $\mathbf{5 0 - 6 0}$ & 5 & 16.67 \\
\hline Total & 30 & 100 \\
\hline
\end{tabular}

AGE WISE DISTRIBUTION OF THE PATIENTS

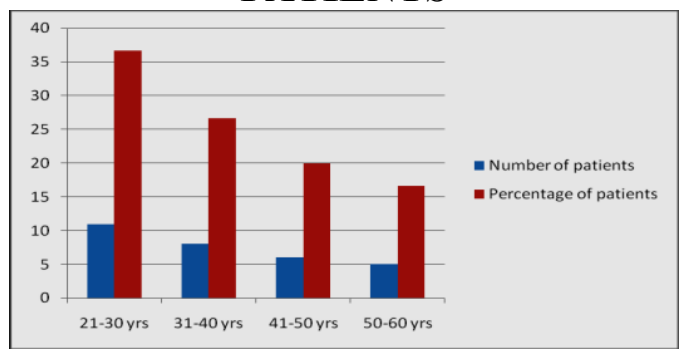

TABLE 2: SHOWING SEX WISE DISTRIBUTION OF PATIENTS

\begin{tabular}{|c|c|c|}
\hline Sex & $\begin{array}{l}\text { Number } \\
\text { of } \\
\text { patients }\end{array}$ & $\begin{array}{l}\text { Percentage } \\
\text { of patients }\end{array}$ \\
\hline Male & 20 & 66.67 \\
\hline Female & 10 & 33.33 \\
\hline Total & 30 & 100 \\
\hline
\end{tabular}




\section{SEX WISE DISTRIBUTION OF \\ PATIENTS}

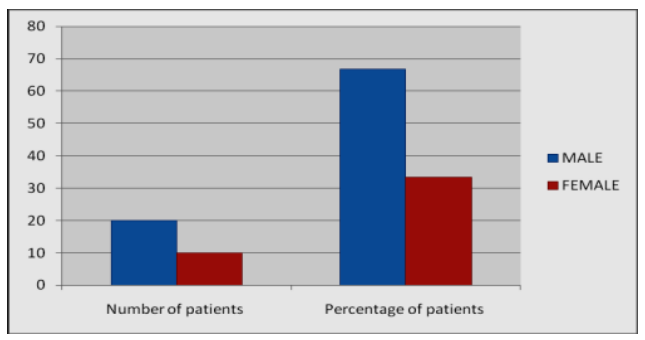

TABLE 3: SHOWING DIET WISE DISTRIBUTION OF THE PATIENTS

\begin{tabular}{|c|c|c|}
\hline Diet & $\begin{array}{c}\text { Number of } \\
\text { patients }\end{array}$ & $\begin{array}{c}\text { Percentage of } \\
\text { patients }\end{array}$ \\
\hline Veg & 14 & 46.67 \\
\hline $\begin{array}{c}\text { Non- } \\
\text { veg }\end{array}$ & 16 & 53.33 \\
\hline Total & 30 & 100 \\
\hline
\end{tabular}

DIET WISE DISTRIBUTION OF THE PATIENTS

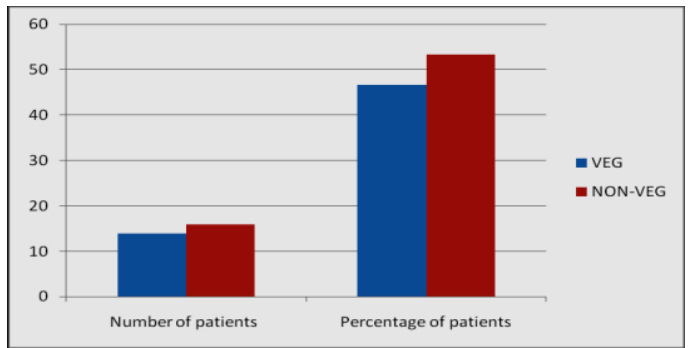

TABLE 4: SHOWING HABITAT WISE DISTRIBUTION OF THE PATIENTS

\begin{tabular}{|c|c|c|}
\hline Habit & $\begin{array}{c}\text { Number } \\
\text { of patients }\end{array}$ & $\begin{array}{c}\text { Percentage } \\
\text { of patients }\end{array}$ \\
\hline Urban & 10 & 33.33 \\
\hline $\begin{array}{c}\text { Sub- } \\
\text { urban }\end{array}$ & 15 & 50 \\
\hline Rural & 5 & 16.67 \\
\hline Total & 30 & 100 \\
\hline
\end{tabular}

\section{HABITAT WISE DISTRIBUTION OF THE PATIENTS}

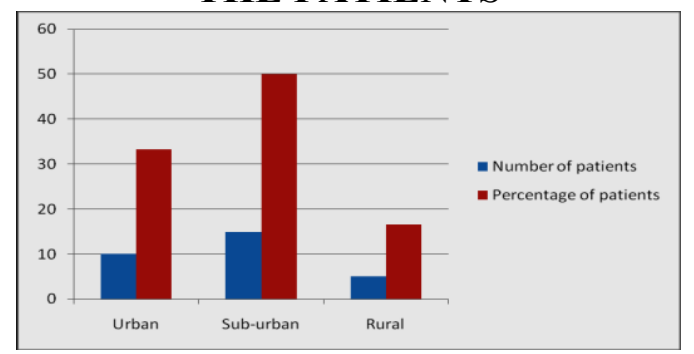

Results:

TABLE 5: SHOWING THE PERCENTAGE OF RELIEF ON OVER ALL PARAMETERS:

\begin{tabular}{|c|c|c|c|c|}
\hline \multirow[b]{2}{*}{ SYMPTOMS } & \multicolumn{2}{|c|}{ No of patients showing the score } & \multirow[b]{2}{*}{ BT-AT } & \multirow[b]{2}{*}{ Percentage of result } \\
\hline & BT & AT & & \\
\hline Diarrhoea & 80 & 7 & 73 & 91.25 \\
\hline Precipitate stool & 46 & 4 & 42 & 91.30 \\
\hline Melena & 41 & 4 & 37 & 90.24 \\
\hline Abdominal cramps & 50 & 10 & 40 & 80 \\
\hline Flatulence & 49 & 6 & 43 & 87.75 \\
\hline Epigastric distress & 51 & 10 & 41 & 80.39 \\
\hline Fatigue & 44 & 5 & 39 & 88.63 \\
\hline Stool examination & 30 & 7 & 23 & 76.67 \\
\hline
\end{tabular}


TABLE 6: SHOWING THE OVERALL RESPONSE TO THE TREATMENT:

\begin{tabular}{|l|c|c|c|c|c|}
\hline \multirow{2}{*}{ Drugs } & \multicolumn{5}{|c|}{ Results of the treatment } \\
\cline { 2 - 6 } & Good & Fair & Poor & No & Total \\
\hline $\begin{array}{l}\text { Daruharidra } \\
\text { Rasakriya }\end{array}$ & 24 & 6 & 0 & 0 & 30 \\
$(80 \%)$ & $(20 \%)$ & & & $(100 \%)$ \\
\hline
\end{tabular}

TABLE 6: SHOWING THE RESULT OF THE TREATMENT:

\begin{tabular}{|c|c|c|c|c|c|c|c|c|}
\hline \multirow[b]{2}{*}{ SYMPTOMS } & \multirow[b]{2}{*}{$\begin{array}{c}\text { No. of } \\
\text { Observations }\end{array}$} & \multicolumn{3}{|c|}{ Mean grade score } & \multirow[b]{2}{*}{ SD } & \multirow[b]{2}{*}{ SE } & \multirow[b]{2}{*}{$\begin{array}{c}\text { 't' } \\
\text { value }\end{array}$} & \multirow[b]{2}{*}{$\begin{array}{c}\text { 'p' } \\
\text { value }\end{array}$} \\
\hline & & BT & $\mathbf{A T}$ & $\begin{array}{l}\text { BT- } \\
\text { AT }\end{array}$ & & & & \\
\hline Diarrhoea & 30 & 2.67 & 0.23 & 2.43 & \pm 0.57 & 0.104 & 23.45 & $<0.0001$ \\
\hline Precipitate stool & 30 & 1.53 & 0.13 & 1.4 & \pm 0.56 & 0.103 & 13.61 & $<0.0001$ \\
\hline Melena & 30 & 1.37 & 0.13 & 1.23 & \pm 0.63 & 0.114 & 10.79 & $<0.0001$ \\
\hline Abdominal cramps & 30 & 1.67 & 0.33 & 1.33 & \pm 0.66 & 0.121 & 11.05 & $<0.0001$ \\
\hline Flatulence & 30 & 1.63 & 0.20 & 1.43 & \pm 0.68 & 0.124 & 11.56 & $<0.0001$ \\
\hline Epigastric distress & 30 & 1.70 & 0.33 & 1.37 & \pm 0.76 & 0.140 & 9.786 & $<0.0001$ \\
\hline Fatigue & 30 & 1.47 & 0.17 & 1.30 & \pm 0.65 & 0.119 & 10.93 & $<0.0001$ \\
\hline Stool examination for cyst & 30 & 1 & 0.23 & 0.77 & \pm 0.430 & 0.079 & 9.76 & $<0.0001$ \\
\hline
\end{tabular}

\section{DISCUSSION}

Pravahika (Amoebiasis) is a disorder mostly affecting the people living in contaminated areas. It is one of the major causes of the death in developing countries. So the present study has been conducted to know the efficacy of Ayurvedic drug, Daruharidra, in the management of the disease. By preparing the Rasakriya of the drug, the dosage is reduced to $1 / 10^{\text {th }}$ of the powdered drug and the palatability increased as it is easy to consume a $300 \mathrm{mg}$ tablet.

Overall result of the above study showed $80 \%$ of the patients showing good response to the treatment and the other $20 \%$ showing fair response. No patient showed poor or no response as compared by the symptomatology. 7 (23.33\%) out of the 30 patients showed the presence of cysts in the stool examination even after the $10^{\text {th }}$ day of the treatment. Even though the stool examination in these 7 patients was positive for the cysts, symptomatically they showed fair response to the treatment.

Statistical analysis of the each symptom showed highly significant result $(p<0.0001)$. Stool examination also significant results $(\mathrm{p}<0.0001)$.
The net result of the study proved to be highly significant by the statistical and percentage analysis. This may be ascribed to the properties of the Daruharidra as mentioned in the classical Ayurvedic texts.

\section{Conclusion}

To summarize the data it can be concluded that the Rasakriya of Daruharidra helps in the treatment of the Pravahika (Amoebiasis) effectively. This may because of the chemical chemical content Berberine in it, which has the antimicrobial and antiprotozoal properties. As mentioned in the classical texts Daruharidra is having the properties of deepana, paacana, grahi and krimi hara properties. These properties are required for the treatment of the disease. So Daruharidra proved efficacious in the cases of Pravahika.

\section{Acknowledgements:}

The author Dr. S. Pavan Kumar is thankful to the Principal, Govt Ayurvedic Medical College and NTRUHS for providing the opportunity to carry out this work. 


\section{REFERENCES:}

1. Atridev. Sushrutha Samhita Hindi translation. $5^{\text {th }}$ Edition. Delhi; Motilal Banarsidas publishers; 1975; 706-710.

2. Nadkarni AK, Nadkarni KM. Indian Materia Medica, Vol I. $3^{\text {rd }}$ Edition. Bomaby; Popular Prakashan; 1976. 187



3. Srikantha Murthy. Bhavaprakasa of Bhavamisra, Vol I, Varanasi; Chowkhamba Krishnadas Academy; 2004. 192

4. Jaruwan Wongbutdee. Physiological Effects of Berberine. Thai Pharm Health Sci J. 2008;4(1):78-83

Figure 1: Daruharidra stem pieces

Figure 2: Rasakriya of Daruharidra

Figure 3: Rasakriya made into pills of $300 \mathrm{mg}$ 